\title{
Availability of Adequately Iodized Salt at Household Level and Associated Factors in Gondar Town, Northwest Ethiopia
}

\author{
Hailay Gebrearegawi Gebremariam, ${ }^{1}$ Melkie Edris Yesuf, ${ }^{2}$ and Digsu Negese Koye ${ }^{3}$ \\ ${ }^{1}$ North Gondar Zonal Health Department, Gondar, Ethiopia \\ ${ }^{2}$ Department of Human Nutrition, Institute of Public Health, College of Medicine and Health Sciences, University of Gondar, \\ Gondar, Ethiopia \\ ${ }^{3}$ Department of Epidemiology and Biostatistics, College of Medicine and Health Sciences, University of Gondar, \\ P.O. Box 196, Gondar, Ethiopia
}

Correspondence should be addressed to Digsu Negese Koye; digsuneg@gmail.com

Received 30 March 2013; Accepted 13 May 2013

Academic Editors: C. Rissel and M. J. Toole

Copyright (C) 2013 Hailay Gebrearegawi Gebremariam et al. This is an open access article distributed under the Creative Commons Attribution License, which permits unrestricted use, distribution, and reproduction in any medium, provided the original work is properly cited.

\begin{abstract}
Background. Iodine deficiency has serious effects on body growth and mental development. This study assessed availability of adequately iodized salt at household level and associated factors in Gondar town, northwest Ethiopia. Methods. Community based cross-sectional study was carried out among households in Gondar town during August 15-25, 2012. Multistage sampling technique was used. Data were collected using a pretested and structured questionnaire by a face-to-face interview technique. Bivariate and multivariate analyses were performed to check associations and control confounding. Results. A total of 810 participants were participated. The availability of adequately iodized salt ( $\geq 15$ parts per million) in the study area was $28.9 \%$. Multivariate analysis showed that using packed salt $(\mathrm{AOR}(95 \% \mathrm{CI})=9.75(5.74,16.56))$, not exposing salt to sunlight $(\mathrm{AOR}(95 \% \mathrm{CI})=7.26(3.73,14.11))$, shorter storage of salt at household (AOR $(95 \%$ CI) $=3.604(1.402,9.267))$ and good knowledge of participants about iodized salt $(\mathrm{AOR}(95 \% \mathrm{CI})=1.94(1.23,3.05))$ were associated with availability of adequately iodized salt at household level. Conclusions. Availability of adequately iodized salt at household level was very low. Hence, households should be sensitized about importance of iodized salt and its proper handling at the household level.
\end{abstract}

\section{Background}

Iodine is essential in small amounts for normal physiologic function. It is a critical component of thyroid hormones, which are necessary for controlling metabolic rate, growth, and development of body structures, as well as neuronal function and development. The World Health Organization (WHO) recommended intake (population requirement) of iodine is $150 \mu \mathrm{g} /$ day for adults and adolescents 13 years of age and older, $200 \mu \mathrm{g} / \mathrm{day}$ for women during pregnancy and lactation, $120 \mu \mathrm{g} /$ day for children 6-12 years of age, and $90 \mu \mathrm{g} /$ day for children $0-59$ months of age [1].

Healthy humans require iodine, an essential component of the thyroid hormones, thyroxin, and triiodothyronine.
Failure to have adequate iodine leads to insufficient production of these hormones, which affect many different parts of the body, particularly muscle, heart, liver, kidney, thyroid gland, and the developing brain. Inadequate hormone production adversely affects these tissues resulting in the disease states known collectively as iodine deficiency disorders (IDD). These include mental retardation, defects in development of the nervous system, goiter, physical sluggishness, growth retardation, reproductive failure, increased childhood mortality, and economic stagnation. The most devastating of these consequences are on the developing human brain [2].

Iodine deficiency disorders are major public health problems in several areas of the world, especially in developing countries. It has been reported that 2.2 billion people $(38 \%$ 
of the world's population) live in areas with iodine deficiency and are at risk of its complications [3]. At least 350 million Africans are at risk of iodine deficiency. According to WHO estimates, goiter presents in $28.3 \%$ of the African population and approximately $25 \%$ of the global burden of iodine deficiency as measured by disability-adjusted life years occurs in Africa [4].

Approximately $70 \%$ of households in the world used iodized salt by 2000, compared with less than $20 \%$ in 1990 . The elimination of iodine deficiency, by expedient production, marketing, and universal consumption of iodized salt, represents a significant development effort in public nutrition. Although globally iodine nutrition has greatly improved, $20 \%$ to $30 \%$ of pregnancies and thus newborns still do not fully benefit from the use of iodized salt [5].

Universal salt iodization has been extremely effective at reducing the burden of IDD and represents a major global public health success. In Africa, great progress has been made towards the elimination of iodine deficiency, saving millions of children from its adverse effects, largely due to the increased household availability of iodized salt [6].

In Ethiopia, one out of every 1000 is a cretin mentally handicapped, due to a congenital thyroid deficiency, and about 50,000 prenatal deaths are occurring annually due to iodine deficiency disorders. Of the total population, $26 \%$ have goiter and $62 \%$ are at risk of IDD according to national survey made by the previous Ethiopian Nutrition Institute [7]. According to the Ethiopian Demographic and Health Survey (EDHS), only 15.4 percent of the households were using iodized salt [8]. Many potential barriers have been identified to receive adequate iodine intake and reducing IDD. Some of these include household salt washing, impurities in salt, salt packaging, education, and environmental factors (moisture, light, heat, and contaminants). Thus, this study assessed availability of adequately iodized salt at household level and associated factors in Gondar town, northwest Ethiopia.

\section{Methods}

2.1. Study Design, Period, and Setting. Community-based cross-sectional study design was carried out during August 15-25, 2012, in Gondar town which is located in North Gondar Zone of Amhara National Regional State. Gondar is $750 \mathrm{~km}$ northwest of Addis Ababa. It is one of the 3 administrative towns in the Amhara National Regional State. The town is divided into 12 administrative areas. According to the 2007 Ethiopian census report, Gondar has a total population of 206, 987 [9].

2.2. Study Population and Sampling Procedures. The study population consists of people residing in selected administrative areas of Gondar town and selected using multistage sampling technique. The sample size was determined by using single population proportion formula. The following assumptions were made: $9.6 \%$ proportion of iodinated salt [8], 95\% confidence level, 3\% margin of error, and design effect of 2 . Then, $10 \%$ was added for the expected nonresponse, making the final sample size 814 .
First, 4 administrative areas were selected using simple random sampling technique. Then, sample was allocated proportional to the household size of each administrative area. The first household from each administrative area was identified using lottery method, and then, systematic random sampling technique was applied to identify the next household to be included. The member of the household who is responsible for purchasing food items and mostly involved in food preparation in the selected households was interviewed.

2.3. Data Collection. Data were collected using structured questionnaire by a face-to-face interviewing technique. The questionnaire was developed in English and then translated into Amharic, and finally, it was retranslated into English by another language translator for checking consistency. The questionnaire sought information on socio-demographic characteristics, income, educational status, knowledge, environmental factors, and availability and accessibility of iodized salt. To assess the use of iodized salt at the household level, interviewers asked households to provide a teaspoon of salt used for cooking. The salt was tested for iodine using the iodine rapid test kit (MBI Kits International). Data were collected by 8 female diploma nurses. Three B.S. nurses were recruited as supervisors. Data collectors and supervisors were trained for two days prior to the data collection.

2.4. Data Management and Analysis. After data collection, each questionnaire was checked for completeness and consistency by supervisors. The data were entered by Epi Info version 3.5.3 statistical package and then transferred to SPSS version 20 for analysis. Association between dependent and independent variables was assessed by using logistic regression. Variables having $P$ value $\leq 0.2$ in the bivariate analysis were entered into multiple logistic regression model for control of confounding. Odds ratio with 95\% confidence interval was used to show associations. $P$ value of $\leq 0.05$ was considered statistically significant in the multivariate analysis. Adequately iodized salt at household level was defined as salt sample which has $\geq 15$ parts per million (PPM) of iodine. Participants who scored above the mean for knowledge questions were considered as having good knowledge about iodized salt.

2.5. Ethical Considerations. Ethical clearance was obtained from Institutional Review Board of the Institute of Public Health, University of Gondar. A formal letter of cooperation was written to Gondar town city administration. After the purpose of the study was explained, verbal consent was obtained from each study participant. Interviews were carried out privately in a separate room. Participants was also informed that participation was on voluntary basis and that they can withdraw at any time if they are not comfortable about the questionnaire. Names or personal identifiers were not included in the written questionnaires to ensure participants' confidentiality. Health education on the importance and source of adequately iodized salt and proper handling 
of it at household level was given by the data collectors for households with inadequate iodized salt.

\section{Results}

3.1. Sociodemographic Characteristics of the Study Participants. A total of 810 participants were included with response rate of $95.5 \%$. The mean age \pm standard deviation of participants was 38 years \pm 12.49 years. Of 810 participants, $714(88.1 \%)$ were Amhara by ethnicity, $682(84.2 \%)$ were Orthodox Christians, 508 (62.7\%) were married, 453 (55.9\%) were housewives, and 186 (23\%) had at least secondary school level in education. Six hundred and eight (75.1\%) of them had family size $\leq 5$, and of monthly income 262 (32.3\%) of participants was $\geq 2000$ Ethiopian Birr (Table 1).

\subsection{Availability of Adequately Iodized Salt at the Household} Level. Adequately iodized salt ( $\geq 15 \mathrm{ppm}$ ) was found in 234 (28.9\%) of the 810 tested salt samples of households. Before testing the salt, $659(81.4 \%)$ participants said that they did not have adequately iodized salt, and 151 (18.6\%) participants said that they have adequately iodized salt for cooking food. From those who said we had iodized salt, the majority $(85.8 \%)$ have got it from supermarkets.

After testing the salt sample using rapid test kits, among those who said that they had iodized salt, $115(76.2 \%)$ households have adequately iodized salt. Out of those who said that they did not have iodized salt, the salt sample shows 119 (18.1\%), 411 (62.4\%), and 129 (19.6\%) $\geq 15$ ppm, $<15 \mathrm{ppm}$, and $0 \mathrm{ppm}$ respectively. The main reasons given for not having adequately iodized salt were lack of knowledge about the benefit of iodized salt (73.1\%), being expensive compared with common salt (24.4\%), shortage of iodized salt in the market at certain times (14.8\%), being less salty $(11.8 \%)$, and not giving attention to it $(9.7 \%)$.

Six hundred and sixty nine $(83 \%)$ households use nonpacked salt; of these 544 (81.5\%) were inadequately iodized. The remaining 141 (17\%) households used packed salt, and out of these $109(77.3 \%)$ were adequately iodized salt. When asked if they have ever heard of iodized salt, 482 (59.5\%) said that they have heard about iodized salt from different sources. Out of those 329 (40.6\%) of the participants have got the information from television. The remaining 328 (40.5\%) participants had not heard about iodized salt.

Regarding knowledge of participants about the usefulness of iodized salt and consequence of IDD, three quarters $(74.8 \%)$ of them had poor knowledge. Almost all of them, 804 (99.3\%), stored salt in a dry place away from humidity and fire area. However, 184 (22.7\%) of the participants expose salt to sunlight when it becomes humid, and 28 (3.5\%) of them wash salt to remove its impurities (Table 2).

3.3. Factors Associated with Availability of Iodized Salt at Household Level. The investigation on the presence of association between suspected factors and availability of adequately iodized salt revealed the following results. Education, occupation, using packed salt, salt not exposed to sunlight, duration of salt storage at home, and knowledge were significantly
TABLE 1: Sociodemographic characteristics of participants at Gondar town, northwest Ethiopia, 2012.

\begin{tabular}{|c|c|c|}
\hline Variables & Frequency & Percent (\%) \\
\hline \multicolumn{3}{|l|}{ Sex } \\
\hline Male & 54 & 6.7 \\
\hline Female & 756 & 93.3 \\
\hline \multicolumn{3}{|l|}{ Age } \\
\hline $18-24$ & 73 & 9.0 \\
\hline $25-34$ & 286 & 35.3 \\
\hline $35-44$ & 209 & 25.8 \\
\hline $45-54$ & 123 & 15.2 \\
\hline $55-64$ & 82 & 10.1 \\
\hline$\geq 65$ & 37 & 4.6 \\
\hline \multicolumn{3}{|l|}{ Ethnicity } \\
\hline Amhara & 714 & 88.1 \\
\hline Tigrie & 84 & 10.4 \\
\hline Others & 12 & 1.5 \\
\hline \multicolumn{3}{|l|}{ Religion } \\
\hline Orthodox & 682 & 84.2 \\
\hline Muslim & 123 & 15.2 \\
\hline Protestant & 5 & 0.6 \\
\hline \multicolumn{3}{|l|}{ Marital status } \\
\hline Single & 68 & 8.4 \\
\hline Married & 508 & 62.7 \\
\hline Divorced & 69 & 8.5 \\
\hline Widowed & 145 & 17.9 \\
\hline Separated & 20 & 2.4 \\
\hline \multicolumn{3}{|l|}{ Educational status } \\
\hline Cannot read and write & 218 & 26.9 \\
\hline Can read and write only & 171 & 21.1 \\
\hline Grades $1-8$ & 147 & 18.1 \\
\hline Grades 9-12 & 186 & 23.0 \\
\hline Above secondary school & 88 & 10.9 \\
\hline \multicolumn{3}{|l|}{ Occupation } \\
\hline Housewife & 453 & 55.9 \\
\hline Daily laborer & 116 & 14.3 \\
\hline Merchant & 94 & 11.6 \\
\hline Government employee & 79 & 9.8 \\
\hline Student & 27 & 3.3 \\
\hline Unemployed & 41 & 5.1 \\
\hline \multicolumn{3}{|l|}{ Income } \\
\hline $300-999$ & 164 & 20.3 \\
\hline $1000-1499$ & 201 & 24.8 \\
\hline 1500-1999 & 183 & 22.6 \\
\hline$>2000$ & 262 & 32.3 \\
\hline \multicolumn{3}{|l|}{ Family size } \\
\hline$\leq 5$ & 608 & 75.1 \\
\hline$>5$ & 202 & 24.9 \\
\hline
\end{tabular}

associated with availability of adequately iodized salt during bivariate analysis. But only using packed salt, not exposing salt to sunlight, shorter duration of salt storage at home, and knowledge of the participants about iodized salt were 
TABLE 2: Knowledge and practice of participants about iodized salt in Gondar town, 2012.

\begin{tabular}{lcc}
\hline Variables & Frequency & Percent (\%) \\
\hline Knowledge & & \\
$\quad$ Good & 204 & 25.2 \\
$\quad$ Poor & 606 & 74.8 \\
Use cover for their salt container & & \\
$\quad$ Yes & 794 & 98 \\
$\quad$ No & 16 & 2 \\
Place of salt storage & & \\
$\quad$ Dry place & 804 & 99.3 \\
$\quad$ Moisture area & 5 & 0.6 \\
$\quad$ Fire area & 1 & 0.1 \\
Exposure to sunlight & & \\
$\quad$ Yes & 184 & 22.7 \\
$\quad$ No & 626 & 77.3 \\
Washing salt & & \\
$\quad$ Yes & 28 & 3.5 \\
$\quad$ No & 782 & 96.5 \\
Duration of salt storage at household level & & \\
$\quad \leq 2$ months & 748 & 92.3 \\
$>2$ months & 62 & 7.7 \\
\hline
\end{tabular}

significantly associated with availability of adequately iodized salt during multivariate analysis.

Accordingly, those who used packed (table) salt were 9.75 $(\operatorname{AOR}(95 \% \mathrm{CI})=9.75(5.74,16.56))$ times more likely to have adequately iodized salt than those who used non packed salt. Those who did not expose salt to sunlight were 7.26 $(\operatorname{AOR}(95 \% \mathrm{CI})=7.26(3.73,14.11))$ times more likely to have adequately iodized salt than those who expose salt to sunlight.

Shorter storage of salt at home was identified as one of the associated factors for having adequately iodized salt. Those who store salt for less than two months at household level were $3.60(\mathrm{AOR}(95 \% \mathrm{CI})=3.60(1.40,9.27))$ times more likely to have adequately iodized salt than those who store salt for more than two months. Those who had good knowledge about iodized salt were $1.94(\mathrm{AOR}(95 \% \mathrm{CI})=1.94(1.23,3.05))$ times more likely to have iodized salt than those who do have poor knowledge (Table 3).

\section{Discussion}

Availability and consumption of adequately iodized salt must be granted for sustainable elimination of IDD. According to WHO and International Council for Control of Iodine Deficiency Disorders (ICCIDD) standard, elimination of IDD will be possible if more than $90 \%$ of the households consume adequately iodized salt. Ethiopia, in its national guideline for control and prevention of micronutrient deficiencies, has set a goal to virtually eliminate IDD by the year 2005 through universal salt iodization (USI) and an objective to increase access to iodized salt among households up to $80 \%[10,11]$. But according to the EDHS 2011 report, the national coverage of USI was only $15.4 \%$ [8].
This study revealed that $28.9 \%$ of households had adequately iodized salt at household level. This is very low as compared to a study conducted in India which showed that $51 \%$ of households have adequately iodized salt [12]. In studies done in Tanzania, South Africa, and Egypt, the national coverage of iodized salt consumption at the household level was $58.4 \%, 62.4 \%$, and $68.3 \%$, respectively $[13,14]$. In South Sudan, Ghana, Malawi, Benin, and Uganda, adequately iodized salt consumption at household level ranges from $72.9 \%$ to $96 \%$ [15]. This might be due to availability and accessibility of iodized salt in the market, legislation and policies to fortify salt with iodine, and regular followup and monitoring regarding utilization of iodized salt in these countries.

This finding is high as compared to EDHS 2011 report; the national coverage of iodized salt in Ethiopia was $15.4 \%$ and $9.6 \%$ for Amhara region [8]. This difference might be due to study area differences. EDHS was conducted both in urban and rural areas but the present study was conducted entirely in urban setting. Urban dwellers use iodized salt more as compared to rural dwellers as evidenced from EDHS 2011 $[8]$.

Using packed salt at the household level was significantly associated with availability of adequately iodized salt. A study conducted in Canada showed that iodine content of the salt remained constant and its distribution remained uniform for many months when the salt is packed and kept dry, preferably in a cool place and away from strong light [16]. Another study done in Iraq showed that packed salt was mostly adequately iodized compared with non packed salt [17]. This might be due to good transportation system, storage, and keeping it in a suitable environmental condition.

Not exposing salt to sunlight was one of the factors significantly associated with availability of adequately iodized salt. A study conducted in Delhi documented that there was about $31 \%$ iodine loss from iodized salt when exposed to sunlight [18]. A similar study done in London also indicated that exposure to sunlight was associated with loss of iodine level in salt [19]. This might be due to the effect of heat on the iodine content. Another study conducted in Kazakhstan showed that salt that is iodized with iodine slowly loses its iodine content when exposed to sunlight. The halogen iodide over time and exposure to excess oxygen and carbon dioxide slowly oxidizes to metal carbonate and elemental iodine which then evaporates [20].

Duration of salt storage at home was significantly associated with availability of adequately iodized salt. A study conducted in London showed that duration of salt storage had an impact on the level of iodine. Iodized salt will lose $24 \%$ of iodine when stored for 10 weeks [19]. This might be due to the effect of physical or environmental factors like moisture content of the salt, humidity of the atmosphere, light, heat, and weather conditions. A similar study conducted in Colombia showed that the effect of longer storage beyond 2 months aggravated losses of iodine from the salt due to different environmental conditions during storage and distribution [21].

Knowledge of participants about iodized salt was significantly associated with availability of adequately iodized salt. 
TABLE 3: Factors associated with availability of adequately iodized salt at household level in Gondar town, 2012.

\begin{tabular}{|c|c|c|c|c|}
\hline \multirow{2}{*}{ Variables } & \multicolumn{2}{|c|}{ Iodine level } & \multirow{2}{*}{ Crude OR (95\% CI) } & \multirow{2}{*}{ Adjusted OR (95\% CI) } \\
\hline & $\geq 15$ ppm & $<15 \mathrm{ppm}$ & & \\
\hline \multicolumn{5}{|l|}{ Educational level } \\
\hline Formal education & 193 & 399 & $2.088(1.427,3.056)$ & * \\
\hline No formal education & 41 & 177 & 1 & \\
\hline \multicolumn{5}{|l|}{ Occupation } \\
\hline Housewife & 108 & 345 & 1 & \\
\hline Daily labor & 28 & 88 & $1.016(.631,1.638)$ & * \\
\hline Merchant & 31 & 63 & $1.572(.971,2.543)$ & * \\
\hline Government employee & 46 & 33 & $4.453(2.710,7.317)$ & * \\
\hline Student & 8 & 19 & $1.345(.573,3.159)$ & * \\
\hline Others & 13 & 28 & $1.483(.742,2.964)$ & $*$ \\
\hline \multicolumn{5}{|l|}{ Types of salt used } \\
\hline Packed salt & 109 & 32 & $14.82(9.52,23.26)$ & $9.749(5.739,16.56)$ \\
\hline Nonpacked salt & 125 & 544 & 1 & 1 \\
\hline \multicolumn{5}{|l|}{ Duration of salt storage } \\
\hline$\leq 2$ months & 228 & 520 & $4.092(1.738,9.634)$ & $3.604(1.402,9.267)$ \\
\hline$>2$ months & 6 & 56 & 1 & 1 \\
\hline \multicolumn{5}{|l|}{ Exposure to sunlight } \\
\hline Yes & 12 & 172 & 1 & 1 \\
\hline No & 222 & 404 & $7.876(4.290,14.462)$ & $7.258(3.733,14.112)$ \\
\hline \multicolumn{5}{|l|}{ Knowledge } \\
\hline Good & 115 & 89 & $5.288(3.758,7.442)$ & $1.938(1.231,3.05)$ \\
\hline Poor & 119 & 487 & 1 & 1 \\
\hline
\end{tabular}

${ }^{*}$ Nonsignificant from the multivariate logistic regression (backward LR method).

A study done in India identified knowledge as a predictor variable. Another study conducted in Ghana showed the result of increased knowledge regarding the importance of using iodized salt and the effects of its deficiency in the diet of an individual; there has also been an increase in the consumption rate of iodized salt $[22,23]$.

This study has the following limitation: iodine level was determined by taking sample only from the salt, which did not include titration level of iodine in the salt and urinary testing of iodine to determine body iodine level.

\section{Conclusions}

Based on the finding of this study, we can conclude that availability of adequately iodized salt at household level was very low in Gondar town. Using packed salt, not exposing salt to sunlight, shorter storage of salt at household, and good knowledge of participants about iodized salt were identified as factors associated with availability of adequately iodized salt at household level. Hence, households should be sensitized to importance of iodized salt and its proper handling at the household level.

\section{Conflict of Interests}

The authors declare that they have no conflict of interests.

\section{Authors' Contribution}

H. G. Gebremariam designed the study, performed the statistical analysis, and drafted the paper. M. E. Yesuf and D. $\mathrm{N}$. Koye participated in the study design, data collection, and writing the paper. All authors contributed to the data analysis and read and approved the final version of the paper.

\section{Acknowledgments}

The authors would like to thank the Federal Minister of Health of Ethiopia and the Global Fund for technical and financial support of this study.

\section{References}

[1] WHO, Iodine Status Worldwide, WHO Global Database on Iodine Deficiency, World Health Organization Department of Nutrition for Health and Development, Geneva, Switzerland, 2004.

[2] M. Venkatesh and T. John, Salt Iodization for the Elimination of Iodine Deficiency, International Council for Control of Iodine Deficiency Disorders, Amsterdam, The Netherlands, 1st edition, 1995.

[3] C. Wisnu, "Determination of iodine species content in iodized salt and foodstuff during cooking," International Food Research Journal, vol. 15, no. 3, pp. 325-330, 2008. 
[4] O. E. Okosieme, "Impact of iodination on thyroid pathology in Africa," Journal of the Royal Society of Medicine, vol. 99, no. 8, pp. 396-401, 2006.

[5] G. F. Maberly, D. P. Haxton, and F. van der Haar, "Iodine deficiency: consequences and progress toward elimination," Food and Nutrition Bulletin, vol. 24, no. 4, pp. S91-S109, 2003.

[6] A. J. Seal, P. I. Creeke, D. Gnat, F. Abdalla, and Z. Mirghani, "Excess dietary iodine intake in long-term African refugees," Public Health Nutrition, vol. 9, no. 1, pp. 35-39, 2006.

[7] L. Takele, T. Belachew, and T. Bekele, "Iodine concentration in salt at household and retail shop levels in Shebe town, South West Ethiopia," East African Medical Journal, vol. 80, no. 10, pp. 532-539, 2003.

[8] CSA and ICF International, Ethiopia Demographic and Health Survey 2011, Central Statistical Agency and ICF International, Calverton, Md, USA, 2012.

[9] F. Population Census Commision, Summary and Statistical Report of the 2007 Population and Housing Census: Population Size By Age and Sex, Addis Abeba, Ethiopia, 2008.

[10] UNICEF, ICCID, PAMM, and WHO, Monitoring Universal Salt Iodization Program, PAMM/ICCIDD, Ottawa, Canada, 1995

[11] FMOH, National Guideline for Control and Prevention of Micronutrient Deficiencies, Edited by F. H. Department, Federal Ministry of Health, Addis Ababa, Ethiopia, 2010.

[12] L. Bohac and D. Gulati, "Integrating small salt producers in Rajasthan into India's universal salt iodization strategy," IDD News Letter, vol. 33, pp. 4-6, 2009.

[13] P. L. Jooste, M. J. Weight, and C. J. Lombard, "Iodine concentration in household salt in South Africa," Bulletin of the World Health Organization, vol. 79, no. 6, pp. 534-540, 2001.

[14] S. Izzeldin, Latest Status of Iodine Nutrition, World Health Organization Regional Office for the Eastern Mediterranean, Permanent Advisory Committee in Nutrition, 2010.

[15] G. Goindi, M. Karmarkar, U. Kapil, and J. Jaganathan, "Estimation of losses of iodine during different cooking procedures," Asia Pacific Journal of Clinical Nutrition, vol. 4, pp. 225-227, 1995.

[16] W. Davidson, M. Finlayson, and C. Watson, "Iodine deficiency disorder," The Journal of Agricultural Science, vol. 31, p. 148, 2005.

[17] S. Ebrahim and N. Muhammed, "Consumption of iodized salt among households of Basra city, South Iraq," Eastern Mediterranean Health Journal, vol. 18, no. 9, pp. 980-984, 2012.

[18] U. Kapil, S. Prakash, and D. Nayar, "Study of some factors influencing losses of iodine from iodised salt," Indian Journal of Maternal and Child Health, vol. 9, no. 1, pp. 46-47, 1998.

[19] F. C. Kelly, "Studies on the stability of iodine compounds in iodized salt," Bulletin of the World Health Organization, vol. 9, no. 2, pp. 217-230, 1953.

[20] K. Waszkowiak and K. Szymandera, "Effect of storage conditions on potassium iodide stability in iodised table salt and collagen preparations," International Journal of Food Science \& Technology, vol. 43, no. 5, pp. 895-899, 2008.

[21] L. L. Diosady, "Stability of iodine in iodized salt used for correction of iodine deficiency disorders," Food and Nutrition Bulletin, vol. 2, pp. 240-250, 2004.

[22] B. Strange, M. Joseph, S. Kaushik, S. Dey, S. Dutt, and R. Jha, "Reaching the rural poor in India with iodized salt: the Micronutrient Initiative's Iodized Salt Coverage Study 2010," IDD News Letter, vol. 39, pp. 6-8, 2011.

[23] C. Buxton and B. Baguune, "Knowledge and practices of people in Bia District, Ghana, with regard to iodine deficiency disorders and intake of iodized salt," Archives of Public Health, vol. 70, pp. 70-75, 2012. 


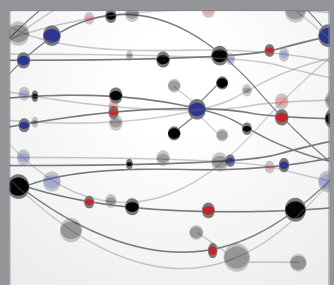

The Scientific World Journal
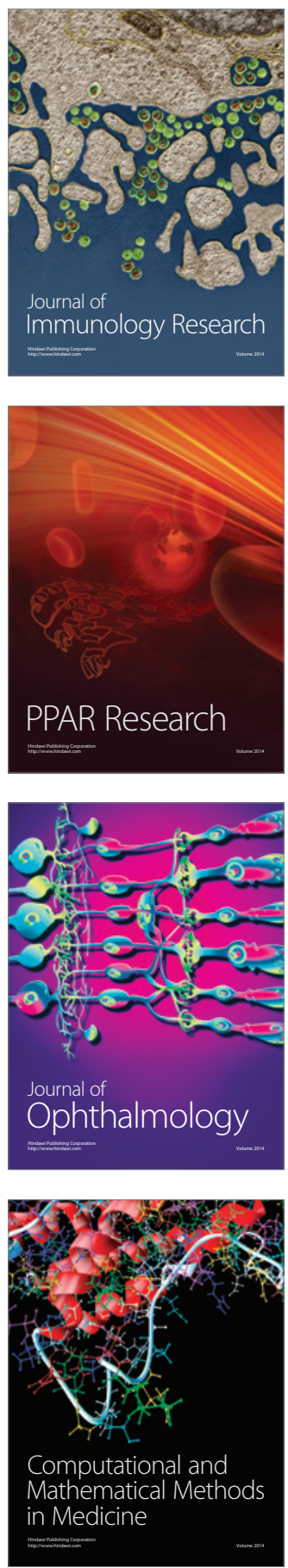

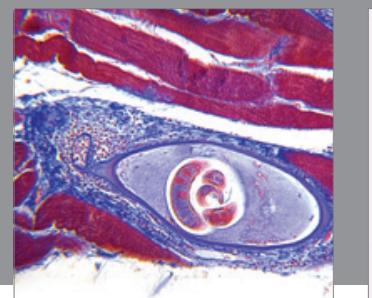

Gastroenterology

Research and Practice
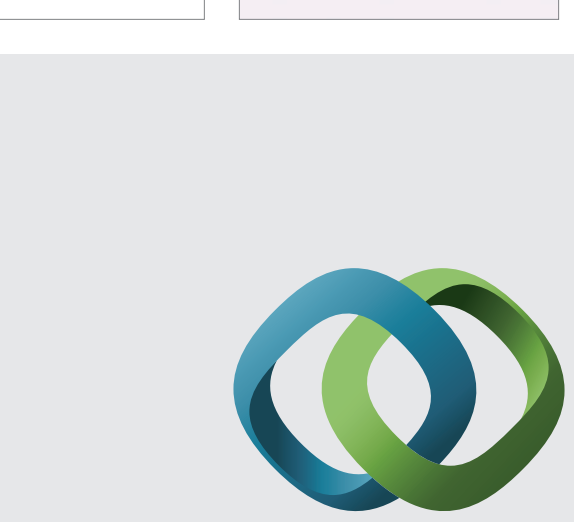

\section{Hindawi}

Submit your manuscripts at

http://www.hindawi.com
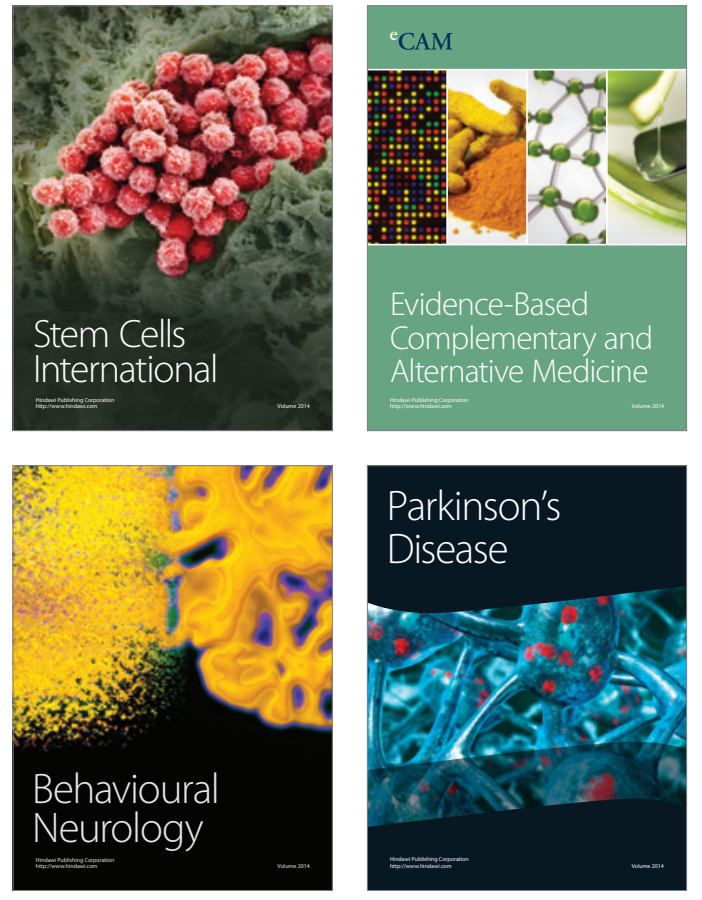
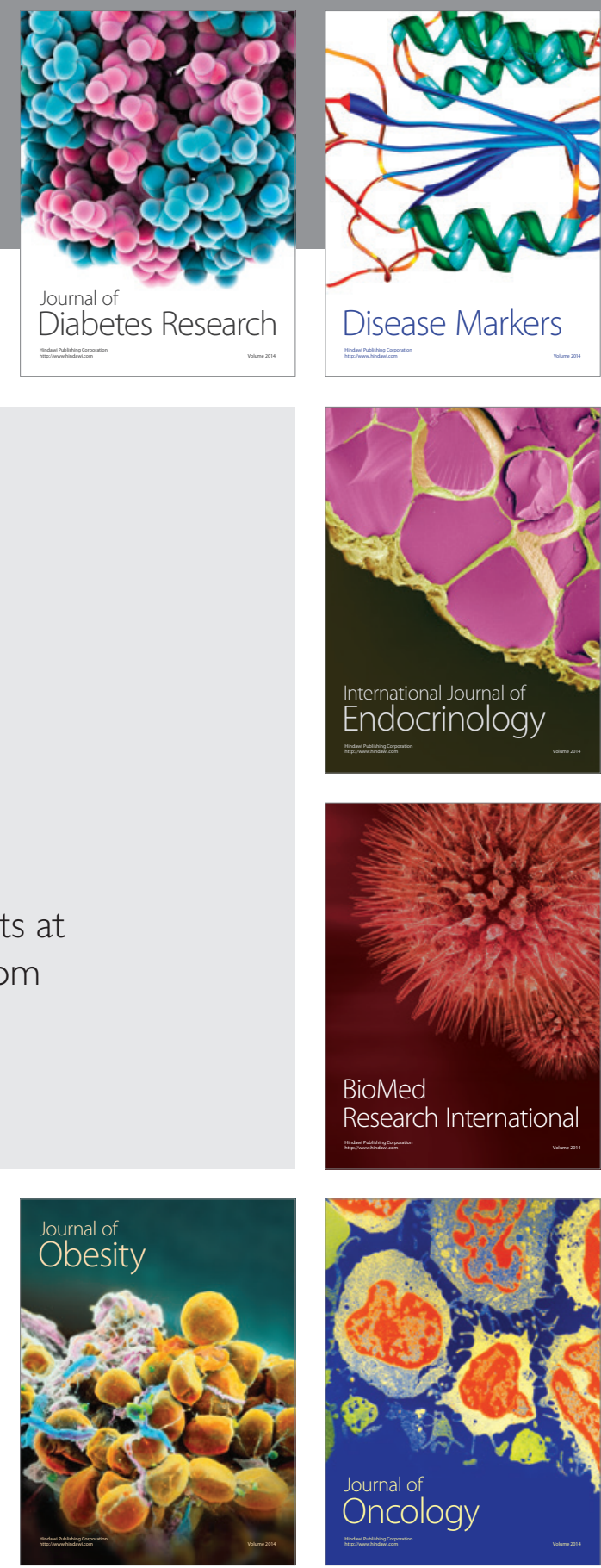

Disease Markers
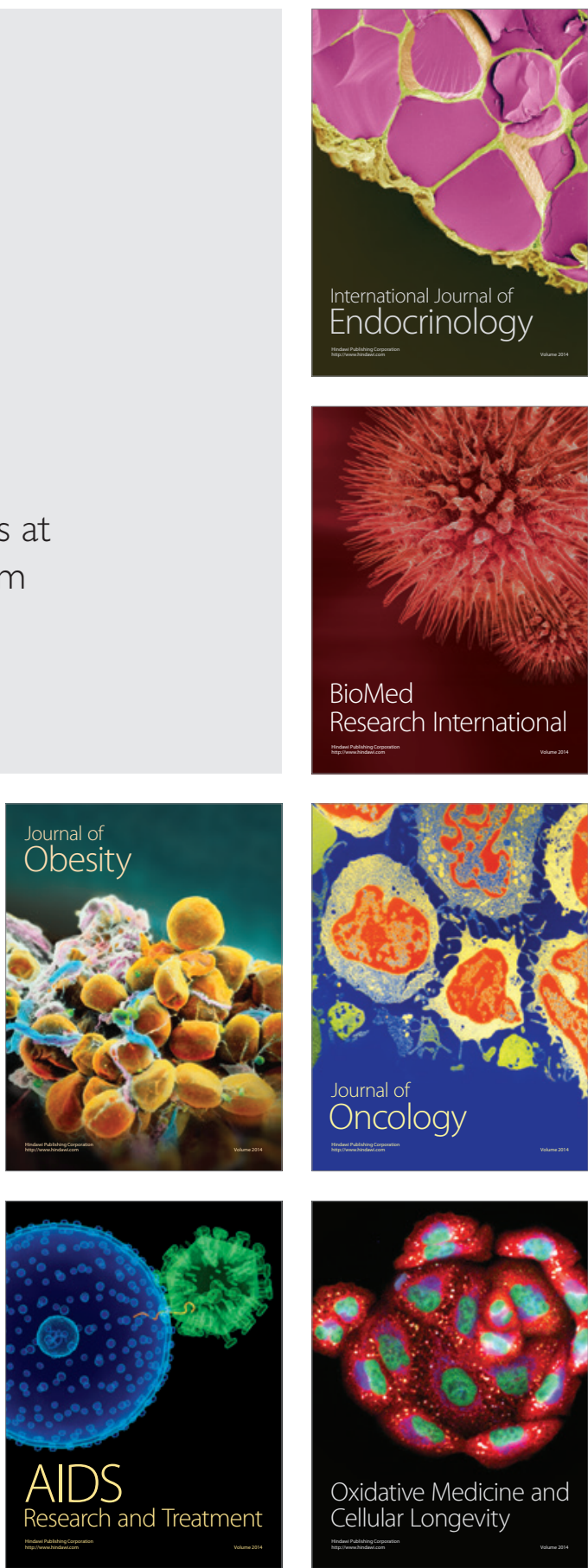